\title{
Estimasi Dosis Radiasi 210Po pada Ikan Laut Konsumsi dari Perairan Banda Aceh
}

\author{
Risa Chintia Balqis ${ }^{*}$, Febriani', Murdahayu Makmur² \\ I Jurusan Kimia, Fakultas Matematika dan Ilmu Pengetahuan Alam, Universitas Syiah Kuala \\ Jl. Syech Abdurrauf No.3. Kec. Syiah Kuala, Kota Banda Aceh, Aceh 23111 Indonesia \\ 2Radioekologi Kelautan Pusat Teknologi Keselamatan dan Metrologi Radiasi, Badan Tenaga Nuklir Nasional \\ Jl. Lebak Bulus Raya No. 49. Jakarta Selatan, 12440 Indonesia \\ Email: rcbalqis@gmail.com
}

\begin{abstract}
The ${ }^{210}$ Po Radiation Dose Estimation of Marine Fish Consumption from Banda Aceh Waters
\end{abstract}

The main idea of this study is to calculate $210 \mathrm{Po}$ activity in marine biota from Banda Aceh waters and calculate dose estimates for marine biota consumers. Polonium analysis was carried out for Kaka Tua fish, Layur fish, Talang-talang fish, Kawet fish, and sharks using alpha spectrometer. The highest 210Po activity was found in sharks at $16.90 \mathrm{~Bq} / \mathrm{kg}$ and Kaka tua fish at $16.24 \mathrm{~Bq} / \mathrm{kg}$. This activity is slightly above the recommended value for seafood, which is $15 \mathrm{~Bq} / \mathrm{kg}$. Based on the calculation, the daily intake for adults is around 0.18-0.41 Bq, for children, it is 0.12-0.27 Bq, and infant are 0.06-0.14 Bq. The daily intake of adults and children exceeds the recommended annual intake limit. However, the annual intake of many countries in the Asian region, including Japan and China, also far exceeds the recommended value. The amount of marine fish consumed significantly influences this annual dose estimate. The estimated dosage of 210Po yearly for adult consumers is 32.3-71.42 $\mu \mathrm{Sv} / \mathrm{year}$ for children, it ranges from 46.65-103.16 $\mu \mathrm{Sv} /$ year, and for infants, it ranges from 78.95-174.58 $\mu \mathrm{Sv} / \mathrm{year}$. These values are similar to the UNSCEAR recommended values: around 70, 100, and $180 \mu$ SV/year for adults, children, and infants.

Keywords: polonium, marine life, fish, Banda Aceh Sea, doses estimation

\begin{abstract}
Abstrak
Ide utama dari penelitian ini adalah untuk menghitung aktivitas 210Po pada biota laut dari perairan Banda Aceh dan menghitung estimasi dosis terhadap konsumen ikan laut. Analisis polonium dilakukan terhadap sampel ikan ikan kaka tua, ikan layur, ikan talang-talang, ikan kawet, dan ikan hiu menggunakan alfa spektrometer. Hasil penelitian menemukan aktivitas 210Po tertinggi pada ikan hiu yaitu 16,90 Bq/ $/ \mathrm{kg}$, dan ikan Kaka tua sebesar 16,24 Bq/kg. Aktivitas ini sedikit diatas nilai yang direkomendasikan untuk makanan laut, yaitu sebesar $15 \mathrm{~Bq} / \mathrm{kg}$. Berdasarkan perhitungan, asupan harian terhadap orang dewasa sekitar 0,18-0,41 Bq, untuk anak anak sebesar 0,12-0,27 Bq dan bayi sebesar 0,06-0,14 Bq. Asupan harian dewasa dan anak melebih batas tahunan asupan yang direkomendasikan, namun asupan tahunan dari banyak Negara di kawasan Asia termasuk Jepang dan China juga jauh melebih nilai yang direkomendasikan Jumlah konsumsi ikan laut sangat berpengaruh terhadap estimasi dosis tahunan ini. Penghitungan estimasi dosis 210Po tahunan terhadap konsumen dewasa adalah sebesar 32,3-71,42 $\mu \mathrm{Sv} /$ tahun, untuk anak anak berkisar antara $46,65-103,16 \mu \mathrm{Sv} /$ tahun dan untuk bayi berkisar antara 78,95-174,58 $\mu \mathrm{Sv} /$ tahun. Nilai ini mirip dengan nilai rekomendasi UNSCEAR, yaitu sekitar 70, 100 dan $180 \mu S v /$ tahun untuk dewasa, anak anak dan bayi.
\end{abstract}

Kata kunci: polonium, biota laut, ikan, perairan laut Banda Aceh, estimasi dosis 


\section{PENDAHULUAN}

Kawasan Asia Tenggara, Indonesia merupakan negara terluas dengan luas lautan Indonesia dua kali lebih besar dibandingkan dengan luas daratannya. Indonesia mempunyai pulau sebanyak 17.504 buah, dengan panjang pantai mencapai $95.181 \mathrm{~km}$, dengan luas perairan 5,8 juta km² yang terdiri atas laut teritorial seluas 0,3 juta $\mathrm{km}$, perairan kepulauan dengan luas 2,8 juta $\mathrm{km}^{2}$, dan perairan Zona Ekonomi Ekskulsif (ZEE) dengan luas 2,7 juta km² (Poerwadi, 2017).

Perairan laut Indonesia mempunyai potensi lestari sumber daya ikan atau maximum sustainable yield (MSY) sebesar 6,5 juta ton per tahun, dengan jumlah tangkapan yang diperbolehkan sebesar 5,2 juta ton/tahun (80\% dari MSY). Berdasarkan data FAO pada tahun 2012 Indonesia menempati peringkat ke-2 untuk produksi perikanan tangkap dan peringkat ke-4 untuk produksi perikanan budidaya di dunia (Bappenas, 2014). Aceh, sebagai provinsi paling barat Indonesia, termasuk yang memiliki sumber daya laut berlimpah dengan kondisi hidrooseanografi yang dinamis, menyediakan habitat utama bagi ikan yang tersebar di berbagai penjuru perairannya (Rizwan et al., 2010).

Untuk menjaga dan melindungi potensi perikanan, baik untuk perikanan tangkap dan budidaya, sangat penting untuk menjaga kualitas lingkungannya serta tidak ada pencemaran baik yang berasal dari lingkungan luar yang masuk ke perairan laut (Bappenas, 2014). Salah satu pencemar yang belakangan ini menjadi perhatian adalah pencemar radioaktif yang berasal dari alam yaitu polonium yang banyak terakumulasi di laut (Kim et al., 2017). Polonium-210 (210Po) adalah radionuklida alami yang merupakan deret dari uranium-238 (238U) (Nelson et al., 2017) yang dihasilkan dari buangan berbagai industri. Polonium memiliki aktivitas spesifik yang tinggi $\left(1.66 \times 10^{14} \mathrm{~Bq} / \mathrm{g}\right)$, oleh karena itu, $1 \mathrm{\mu g}$ dari $210 \mathrm{Po}$ memancarkan partikel alfa per detik sebanyak $4,5 \mathrm{mg}$ dari $226 \mathrm{Ra}$ (aktivitas spesifik - 3,66 × $\left.10^{10} \mathrm{~Bq} / \mathrm{g}\right), 262 \mathrm{mg}{ }^{238} \mathrm{Pu}$, atau $446 \mathrm{~kg} 238 \mathrm{U}$ (Ram et al., 2019).
Konsentrasi aktivitas polonium-210 dalam organisme laut sangat bervariasi pada berbagai spesies tertentu, dengan faktor konsentrasi dari $10^{3}$ hingga $10^{6}$ (Khan dan Wesley, 2016). Polonium tercatat memiliki konsentrasi tinggi dibeberapa spesies laut dengan jumlah yang bervariasi tergantung jenis spesies (UNSCEAR, 2000). Studi tentang organisme akuatik, menunjukkan bahwa kontribusi polonium pada plankton dan ikan mencapai $80 \%$ dan bahkan $99 \%$ untuk krustasea (Meganyctiphanes norvegica) (Skwarzec \& Fabisiak, 2007).

Keberadaan polonium di alam umumnya melalui proses industri atau pertambangan. Polonium terlepas ke air limbah tambang batu bara dan atau tambang lainnya (Nelson et al., 2017). Air limbah tambang yang mengandung polonium dapat mencemari ekosistem air, terutama laut karena laut merupakan tujuan akhir dari aliran sungai dan rawa. Akibatnya, air laut dan sedimen menjadi sumber radionuklida bagi organisme laut yang hidup di dalamnya. Proses bioakumulasi pada biota laut dipengaruhi oleh peningkatan konsentrasi dan ketersediaan radionuklida pada spesies yang terdapat pada rantai makanan di laut (Khan \& Wesley, 2016).

Oleh karena polonium memiliki tingkat radioaktivitas yang tinggi (Nathwani et al., 2016), unsur ini menjadi salah satu masalah kesehatan bagi masyarakat yang mengkonsumsi makanan laut, seperti ikan yang telah tercemar oleh polonium (Carvalho, 2018). Kontaminasi unsur radioaktif dalam makanan laut dapat merugikan kesehatan masyarakat sehingga penting untuk mengetahui aktivitas 210Po dalam makanan laut, termasuk menghitung estimasi dosis radiasi terhadap konsumen makanan laut dari $210 \mathrm{Po}$. Tujuan penelitian adalah menghitung aktivitas 210Po pada biota laut dari perairan Banda Aceh dan menghitung estimasi dosis terhadap konsumen ikan laut.

\section{MATERI DAN METODE}

Penelitian dilakukan secara eksperimental di laboratorium melalui beberapa tahapan. Tahap pertama yaitu pengumpulan sampel ikan dilakukan di 
Pelabuhan Perikanan Samudra Kutaraja pada tanggal 15 Februari 2020. Sampel ikan yang dianalisis adalah ikan layur (Trichiurus savala), ikan hiu tikusan (Alopias pelagicus), ikan kaka tua (Scarus chameleon), ikan talang-talang (Scomberomorus queenlandicus), dan ikan kawet (Naso lituratus). Selanjutnya dilakukan preparasi sampel dengan menggunakan metode radiokimia International Atomic Energy Agency (IAEA) dalam modul Guidelines for the Sampling, Preparation and Radio-Analysis of Marine Matrices (IAEA, 2017).

\section{Analisis ${ }^{210}$ Po di laboratorium}

Sebanyak 2 gram sampel ikan yang telah dikeringkan dimasukkan ke dalam gelas beaker $250 \mathrm{~mL}$, ditambahkan 8-10 $\mathrm{mL} \mathrm{HNO}_{3}$ pekat. Kemudian ditambahkan $300 \mu \mathrm{L}{ }^{209} \mathrm{Po}$ tracer $(\sim 0,075 \mathrm{~Bq})$, dan dibiarkan selama

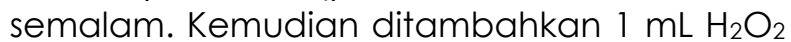
ke dalam sampel dan dievaporasi sampai kering. Tambahkan $6 \mathrm{~mL} \mathrm{HNO}$ pekat dan $1 \mathrm{~mL}$ $\mathrm{H}_{2} \mathrm{O}_{2}$ ke dalam sampel dan dievaporasi sampai kering sebanyak 2 kali ulangan. Setelah itu, ditambahkan $2 \mathrm{~mL} \mathrm{HCl}$ pekat dan kembali dievaporasi sampai kering.

Residu yang telah kering dilarutkan dalam 0,1 M HCl dan disaring. Gelas beaker dan saringan dibilas beberapa kali dengan sedikit $0,1 \mathrm{M} \mathrm{HCl}$. Filtrat dikumpulkan dalam beaker $150 \mathrm{~mL}$ dengan volume sekitar $100 \mathrm{~mL}$. Kemudian ditambahkan 0,5 gram asam askorbat. Larutan diaduk menggunakan magnetic stirrer pada suhu $90^{\circ} \mathrm{C}$ sampai asam askorbat larut dengan sempurna. Setelah asam askorbat larut sempurna, sisipkan silver disk ke dalam larutan dan biarkan pada suhu $90^{\circ} \mathrm{C}$ selama 4 jam. Silver disk dipindahkan dari larutan dan dibilas dengan air deionisasi dan etanol. Aktivitas 210Po dan ${ }^{209} \mathrm{Po}$ dicacah dengan alfa spektrometer.

\section{Penghitungan dosis harian dan dosis tahunan 210Po melalui konsumsi ikan}

Penghitungan laju dosis menggunakan persamaan (Rani et al., 2014; Meli et al., 2014; Khan and Wesley, 2016):

$$
D=I \times Q \times C \times M F
$$

Dimana D adalah laju dosis ( $\mu \mathrm{Sv}$ ) perhari atau per tahun dan I adalah konsumsi ikan tahunan (kg/tahun). Nilai $\mathrm{C}$ adalah aktivitas 210Po dalam ikan $(\mathrm{Bq} / \mathrm{kg})$, dengan rasio asupan untuk orang dewasa, anak-anak dan bayi adalah 3:2:1 (Meli et al., 2014). Q adalah faktor konversi dosis $(\mu \mathrm{Sv} / \mathrm{Bq})$ dan berdasarkan ICRP (International Commision on Radiological Protection) konstanta konversi dosis untuk 210Po, juga berbeda berdasarkan umur dan dikelompokkan menjadi 3 bagian, dewasa, anak-anak dan bayi. (Eckerman et al., 2013). Nilai $M$ adalah faktor koreksi untuk waktu penangkapan dan konsumsi ikan (0.06) (Khan and Wesley, 2016) dan F adalah nilai fraksi konsumsi ikan laut (0.67) (Meli et al., 2014)

\section{HASIL DAN PEMBAHASAN}

\section{Aktivitas ${ }^{210}$ Po pada Ikan Laut}

Aktivitas $210 \mathrm{Po}$ ikan laut dari perairan laut Aceh dianalisis berdasarkan aktivitas tracer ${ }^{209}$ Po yang ditambahkan pada saat analisis dan dari hasil perhitungan didapatkan kisaran aktivitas ${ }^{210} \mathrm{Po}$ pada ikan sebesar $38,22-84,5$ $\mathrm{Bq} / \mathrm{kg}$ kering. Dengan menggunakan asumsi faktor koreksi berat kering ke berat basah ikan sebesar $20 \%$, maka didapatkan aktivitas $210 \mathrm{Po}$ pada ikan berkisar antara 7,64-16,90 Bq/kg basah. Data hasil analisis dapat dilihat pada Tabel 1.

Tabel 1. Hasil analisis polonium pada sampel ikan

\begin{tabular}{lll}
\hline No. & Nama Ikan & Aktivitas $210 \mathrm{Po} \mathrm{Bq} / \mathrm{kg}$ (basah) \\
\hline 1 & Kaka tua (Scarus Chameleon) & $16,24 \pm 2,79$ \\
2 & Hiu (Alopias pelagicus) & $16,90 \pm 2,89$ \\
3 & Kawet (Naso lituratus) & $7,64 \pm 1,50$ \\
4 & Talang talang (Scomberomorus queenlandicus) & $9,26 \pm 1,7$ \\
5 & Layur (Trichiurus savala) & $13,31 \pm 2,36$ \\
\hline
\end{tabular}


Pengukuran aktivitas 210Po yang dilakukan menghasilkan hasil yang berbeda untuk setiap ikan Sampel ikan hiu mempunyai aktivitas 210Po tertinggi yaitu $16,90 \mathrm{~Bq} / \mathrm{kg}$ sedangkan yang terendah dimiliki oleh sampel ikan kawet yaitu $7,64 \mathrm{~Bq} / \mathrm{kg}$. Hasil review global untuk aktivitas $210 \mathrm{Po}$ pada makanan laut merekomendasikan nilai batas sebesar $15 \mathrm{~Bq} / \mathrm{kg}$ (UNSCEAR, 2000), dan aktivitas ikan hiu dan ikan kaka tua sedikit lebih tinggi dari aktivitas yang direkomendasikan. Namun demikian, jumlah konsumsi makanan laut yang sangat bervariasi dari negara negara dan antar individu dalam satu Negara akan berpengaruh terhadap kalkulasi dosis.

Aktivitas 210Po pada ikan hiu $(16,90$ $\mathrm{Bq} / \mathrm{kg}$ ) tidak jauh berbeda dibandingkan dengan ikan kaka tua $(16,24 \mathrm{~Bq} / \mathrm{kg})$. Ikan hiu termasuk ikan pelagis pada rantai makanan predator, dengan panjang badan mencapai $428 \mathrm{~cm}$ dengan siklus hidup yang panjang, merupakan spesies ikan hiu oseanik yang hidup dipermukaan perairan hingga kedalaman $152 \mathrm{~m}$. Sebaran spesies hiu ini diketahui sangat luas di wilayah perairan Indo Pasifik (Almunawwarah, Ibrahim, dan Noviyanti, 2016). Ikan kaka tua (Scarus chameleon) merupakan famili dari Scaridae dengan genus Scarus dikenal sebagai parrotfish, hidup di perairan tropis dan subtropis pada kedalaman 1-25 m dari permukaan laut. Ikan ini biasanya mendapatkan alga dari substrat karang yang mati (Streelman et al., 2002).

Aktivitas $210 \mathrm{Po}$ lebih rendah pada ikan layur $(13.31 \mathrm{~Bq} / \mathrm{kg})$, ikan kawet $(7.64 \mathrm{~Bq} / \mathrm{kg})$ maupun ikan talang talang $(9,26 \mathrm{~Bq} / \mathrm{kg})$. Ikan layur, termasuk ikan besar dengan panjang badan mencapai 2,5 meter, tetapi siklus hidup layur berkisar 8 tahun ssehingga akivitas $210 \mathrm{Po}$ pada ikan layur lebih rendah dibandingkan dengan hiu. Ikan talang talang (Scomberomorus queenlandicus) atau dikenal juga dengan nama Queenfish dan ikan layur (Trichiurus savala) memiliki ordo dan famili yang sama dengan ikan tenggiri, yaitu ordo Scombriformes dan famili Scombridae yang mana salah satu dari sifat ikan tersebut adalah suka bergerombol, sehingga penyebarannya pada suatu perairan tidak merata. Ikan kawet (Naso lituratus) merupakan ikan yang tergolong ke dalam famili Acanthuridae dan termasuk genus Naso, memakan alga dasar, zooplankton atau detritus (Sorenson et al., 2013).

Hasil analisis ini dibandingkan dengan penelitian Makmur pada 2019 yang menganalisis aktivitas 210 Po di beberapa biota laut di Teluk Jakarta, yaitu sekitar 9,05-139 $\mathrm{Bq} / \mathrm{kg}$ (Makmur et al., 2020). Hasil penelitian lain yang dilakukan di perairan Arabian Gulf countries (negara-negara Arab di Teluk Persia) melaporkan aktivitas 210Po pada beberapa biota laut sebesar 0,1-14,7 Bq/kg kering (Ababneh et al., 2018). Analisis 210Po pada ikan tuna dari perairan Kudankulam, India dengan aktivitas berkisar antara 40,9-92,5 Bq/kg basah (Khan and Wesley, 2016), di korea, aktivitas 210Po pada ikan teri berkisar antara 59 -392 $\mathrm{Bq} / \mathrm{kg}$ (Kim et al., 2017), dan di New Zealand, 210Po pada kekerangan berkisar sekitar 4,7 sampai 324 Bq/kg (Guy et al., 2020).

Bervariatifnya konsentrasi aktivitas ${ }^{210} \mathrm{Po}$ pada biota laut disebabkan karena faktor lingkungan dan juga tergantung ke jenis biota. Aktivitas $210 \mathrm{Po}$ pada biota juga tergantung pada musim, dimana kerang dari pesisir Italia dan Slovenia mempunyai aktivitas yang lebih rendah pada musim semi pada bulan Maret sampai Juli (Kristan et al., 2015). Aktivitas 210Po dalam biota laut bervariasi dan tingkat radioaktivitasnya tidak berhubungan dengan jenis ekosistem maupun posisi geografis laut. Banyak penelitian kemudian difokuskan terhadap taksonomi dan tingkatan tropik biota laut (Carvalho et al., 2017).

Radionuklida di lingkungan perairan laut, mengikuti dua mekanisme dasar yang mempengaruhi konsentrasinya pada biota laut, yaitu adsorpsi (dari air laut secara proses fisika kimia masuk ke permukaan eskternal organisme) dan absorpsi (uptake radionuklida melalui makanan, terserap ke dalam jaringan dan organ organisme. Hasil penelitian (Carvalho, 2018) menemukan bahwa, penyerapan $210 \mathrm{Po}$ oleh biota laut lebih banyak melalui makanan dibandingkan dari air laut karena lebih dari $97 \%$ persen terakumuasi di internal. Banyak penelitian membuktikan bahwa 210 Po lebih banyak terserap di organ dalam. Penelitian di korea, dimana pada ikan teri, aktivitas 210Po lebih tinggi di organ dalam (323 Bq/kg) dibandingkan dengan di otot 
$(38,9 \mathrm{~Bq} / \mathrm{kg})$. Demikian juga pada ikan makarel, aktivitas 210Po lebih tinggi pada liver (429 Bq/ $\mathrm{kg}$ ) dibandingkan dengan kulit $(12,6$ $\mathrm{Bq} / \mathrm{kg}$ ) (Kim et al., 2017).

\section{Estimasi Dosis Harian dan Dosis Tahunan 210Po melalui Konsumsi Ikan}

Kajian dosis 210Po dari makanan laut terhadap manusia sangat penting karena konsumsi makanan laut merpakan jalur kritis untuk akumulasi 210Po di manusia, dimana dari hasil penelitian di Syria, aktivitas $210 \mathrm{Po}$ pada ikan laut jauh lebih besar dibndingkan dengan ikan air tawar (Al-Masri et al., 2000). Penghitungan dosis dilakukan untuk mengetahui perpindahan polonium dari lingkungan ke manusia, dimana dari hasil penelitian di Itali, $67 \%$ dosis yang masuk melalui makanan berasal dari komsumsi makanan laut (Meli et al., 2014). Estimasi dosis ini dipengaruhi oleh besaran aktivitas ${ }^{210} \mathrm{Po}$ di dalam makanan laut dan jumlah konsumsi tahunan.

Data Badan pusat statistik pada survey Konsumsi Kalori dan Protein Penduduk Indonesia(BPS, 2020a), jumlah konsumsi ikan basah per kapita di Provinsi Aceh jauh lebih besar yaitu sebesar $29.82 \mathrm{~kg} /$ tahun (BPS Provinsi Aceh, 2020) dibandingkan dengan jumlah komsumsi nasional yaitu $17.8 \mathrm{~kg} /$ tahun (BPS, 2020b). Diasumsikan bahwa konsumsi ikan karang sebesar 30 persen, sehingga nilai komsumsi harian yang digunakan dalam perhitungan ini adalah sekitar $0.024 \mathrm{~kg} /$ hari.

Konstanta konversi dosis berdasarkan ICRP (International Commision on Radiological Protection) untuk 210Po, berbeda-beda berdasarkan umur karena memperhitungkan kecepatan dalam penyerapan usus, massa tubuh dan organ, dan kecepatan ekskresi dari kandung kemih. Sehingga untuk kelompok umur dewasa, disepakati konstanta konversi sebesar 1,2 x 10-6 Sv/Bq, untuk anak anak (10 tahun) $2,6 \times 10^{-6} \mathrm{~Sv} / \mathrm{Bq}$ dan bayi $(<1$ tahun) sebesar 8,8 x 10-6 Sv/Bq (Eckerman et al., 2013; Meli et al., 2014). Data hasil perhitungan dapat dilihat pada Tabel 2.

Asupan harian dari 210Po yang didapatkan dari penelitian ini adalah sekitar 0,18-0,41 Bq untuk dewasa, 0,12-0,27 Bq untuk anak-anak dan 0,06-0,14 Bq untuk bayi dengan akumulasi asupan pertahun berkisar Antara 66,95 - 148,05 Bq untuk dewasa, 44,64 - 98,70 untuk anak-anak dan 22,32-49,35 Bq untuk bayi. UNSCEAR merekomendasi jumlah asupan tahunan maksimal sebesar $58 \mathrm{~Bq}$, dimana asupan tahunan untuk 210Po dari Jepang sekitar $220 \mathrm{~Bq}$, China antara $68-130$ Bq dan India sekitar 20 Bq (UNSCEAR, 2000).

Berdasarkan perhitungan, maka dosis tahunan terhadap konsumen dewasa yang didapatkan dari konsumsi ikan adalah sebesar 32,3-71,42 $\mu S v /$ tahun, untuk anak anak berkisar antara 46,65-103,16 $\mu \mathrm{Sv} /$ tahun dan untuk bayi berkisar antara 78,95-174,58 $\mu S v /$ tahun. Nilai ini mirip dengan nilai rekomendasi UNSCEAR, yaitu sekitar 70, 100 dan $180 \mu \mathrm{Sv} /$ tahun untuk dewasa, anak anak dan bayi (UNSCEAR, 2000; Meli et al., 2014). Dibandingkan dengan data dosis tahunan untuk orang dewasa dari ikan, udang dan kerang dari Teluk Jakarta tahun 2017 yang berkisar antara 0.03-3.6 $\mu \mathrm{Sv} /$ year (Makmur, Prihatiningsih and Yahya, 2020), nilai estimasi dosis dari penelitian ini hampir sama dengan

Tabel 2. Asupan harian dan tahunan ${ }^{210}$ Po dari ikan laut

\begin{tabular}{lcccccc}
\hline \multirow{2}{*}{ Nama Ikan } & \multicolumn{3}{c}{ Asupan (Bq) Harian } & \multicolumn{3}{c}{ Asupan Tahunan } \\
\cline { 2 - 7 } & Dewasa & $\begin{array}{c}\text { Anak- } \\
\text { Anak }\end{array}$ & Bayi & Dewasa & $\begin{array}{c}\text { Anak- } \\
\text { Anak }\end{array}$ & Bayi \\
\hline Kaka tua (Scarus chameleon) & 0,39 & 0,26 & 0,13 & 142,28 & 94,85 & 47,43 \\
Hiu (Alopias pelagicus) & 0,41 & 0,27 & 0,14 & 148,05 & 98,70 & 49,35 \\
Kawet (Naso lituratus) & 0,18 & 0,12 & 0,06 & 66,95 & 44,64 & 22,32 \\
Talang talang & 0,22 & 0,15 & 0,07 & 81,10 & 54,06 & 27,03 \\
(Scomberomorus & & & & & & \\
queenlandicus) & 0,32 & 0,21 & 0,11 & 116,59 & 77,73 & 38,86 \\
Layur (Trichiurus savala) & & & & & & \\
\hline
\end{tabular}


Tabel 3. Estimasi dosis harian dan tahunan $210 \mathrm{Po}$ dari ikan laut

\begin{tabular}{|c|c|c|c|c|c|c|}
\hline \multirow[b]{2}{*}{ Nama lkan } & \multicolumn{3}{|c|}{ Dosis ( $\mu \mathrm{S} v)$ Harian } & \multicolumn{3}{|c|}{ Dosis ( $\mu S v)$ Tahunan } \\
\hline & Dewasa & $\begin{array}{l}\text { Anak- } \\
\text { Anak }\end{array}$ & Bayi & Dewasa & $\begin{array}{l}\text { Anak- } \\
\text { Anak }\end{array}$ & Bayi \\
\hline $\begin{array}{l}\text { Kaka tua (Scarus } \\
\text { chameleon) }\end{array}$ & 0.19 & 0.27 & 0.46 & 68.63 & 99.14 & 167.77 \\
\hline $\begin{array}{l}\text { Hiu (Alopias } \\
\text { pelagicus) }\end{array}$ & 0.20 & 0.28 & 0.48 & 71.42 & 103.16 & 174.58 \\
\hline $\begin{array}{l}\text { Kawet (Naso } \\
\text { lituratus) }\end{array}$ & 0.09 & 0.13 & 0.22 & 32.30 & 46.65 & 78.95 \\
\hline $\begin{array}{l}\text { Talang talang } \\
\text { (Scomberomorus } \\
\text { queenlandicus) }\end{array}$ & 0.11 & 0.15 & 0.26 & 39.12 & 56.51 & 95.63 \\
\hline $\begin{array}{l}\text { Layur (Trichiurus } \\
\text { savala) }\end{array}$ & 0.15 & 0.22 & 0.38 & 56.24 & 81.24 & 137.49 \\
\hline
\end{tabular}

estimasi dosis dari makanan laut di Italia sekitar

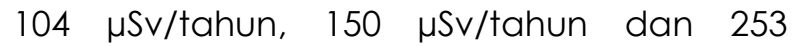
$\mu S v /$ tahun untuk dewasa, anak anak dan bayi (Meli et al., 2014).

Nilai estimasi dosis dewasa kekerangan di India sekitar 2,24 mSv/tahun (Macklin Rani et al., 2014), kekerangan dari pantai selatan India sekitar 5,1-34,9 $\mathrm{SS}$ /tahun (Khan, Wesley and Rajan, 2014) dan pada ikan tuna di Kudamkulam India sebesar 62,7-126,4 MSv/tahun (Khan and Wesley, 2016) serta pada konsumen makanan laut di New Zealand sekitar 1,87-3,61 mSv/tahun (Pearson et al., 2016).

Setelah dikonsumsi, nuklida 210Po didalam tubuh akan berpindah dari usus ke darah, dan proses penyerapannya akan tergantung ke usia konsumen. Sorpsi tertinggi, sekitar $100 \%$ akan terjadi pada bayi dan $50 \%$ penyerapan pada konsumen usia lain(Carvalho et al., 2017) dan kemudian seiring waktu akan terdistribusi kedalam organ dan jaringan dan dalam jangka panjang akan terjadi pertukaran 210 Po antara ginjal, hati, dan kerangka.

Perkiraan nilai asupan dosis per organ, diasumsikan bahwa untuk 210po yang memasuki sirkulasi sistemik, disimpan di limpa, ginjal, sumsum tulang merah, hati dan seluruh tubuh dengan sebesar $0,05,0,1,0,1,0,3$ dan 0,45 selama waktu paruh 50 hari. Untuk 210Po yang kemudian memasuki sistem ekskresi dengan asumsi rasio ekskresi melalui urin banding feses sebesar 0,5 (Carvalho et al., 2017)

\section{KESIMPULAN}

Hasil penelitian menemukan aktivitas $210 \mathrm{Po}$ tertinggi pada ikan hiu yaitu $16,90 \mathrm{~Bq} / \mathrm{kg}$, dan ikan Kaka tua sebesar 16,24 Bq/kg, sedikit diatas nilai yang direkomendasikan untuk makanan laut, yaitu sebesar $15 \mathrm{~Bq} / \mathrm{kg}$. Berdasarkan perhitungan asupan harian terhadap orang dewasa sekitar $0,18-0,41 \mathrm{~Bq}$, untuk anak anak sebesar 0,12-0,27 Bq dan bayi sebsar 0,06-0,14 Bq, maka estimasi dosis 210Po tahunan terhadap konsumen dewasa adalah sebesar 32,3 - 71,42 $\mu \mathrm{S} v /$ tahun, untuk anak anak berkisar antara 46,65 - 103,16 $\mu S v /$ tahun dan untuk bayi berkisar antara $78,95-174,58 \mu \mathrm{S} v /$ tahun. Nilai ini mirip dengan nilai rekomendasi UNSCEAR, yaitu sekitar 70 , 100 dan $180 \mu \mathrm{Sv} /$ tahun untuk dewasa, anak anak dan bayi. Jumlah konsumsi ikan laut sangat berpengaruh terhadap estimasi dosis tahunan ini.

\section{UCAPAN TERIMA KASIH}

Terima kasih kepada Bapak dan Ibu Peneliti di Radioekologi Kelautan BATAN yang telah mengarahkan dan membimbing kegiatan penelitian di Laboratorium Radioekologi. Terima kasih juga kepada jurusan Kimia Universitas Syiah Kuala atas izin melakukan Kerja Praktek di BATAN. 


\section{DAFTAR PUSTAKA}

Ababneh, Z.Q., Ababneh, A.M., Almasoud, F.I., Alsagabi, S., Alanazi, Y.J., Aljulaymi, A.A. \& Aljarrah, K.M., 2018. Assessment of the committed effective dose due to the 210Po intake from fish consumption for the Arabian Gulf population, Chemosphere, 210:511-515. doi: 10.1016/j.chemosphere. 2018.07.045.

Al-Masri, M.S., Mamish, S., Budeir, Y. \& Nashwati, A., 2000. 210Po and 210Pb concentrations in fish consumed in Syria. Journal of Environmental Radioactivity, $49(3): 345-352$.

Bappenas. 2014. Kajian Strategi Pengelolaan Perikanan Berkelanjutan, Kementerian PPN/Bapenas Direktorat Kelautan dan Perikanan.

BPS. 2020a. Konsumsi Kalori dan Protein Penduduk Indonesia dan Provinsi, Maret 2020. Edited by A. Chamami and I. Sahara. Jakarta: Badan Pusat Statistik. Available at: https://www.bps.go.id/publi cation/download.html.

BPS. 2020b. Perkembangan Beberapa Indikator Utama Sosial-Ekonomi Indonesia 2020. Jakarta: BPS-Statistics Indonesia.

BPS Provinsi Aceh. 2020. Statistik Pengeluaran Rumah Tangga Provinsi Aceh.

Carvalho, F., Fernandes, S., Fesenko, S., Holm, E., Howard, B., Martin, P., Phaneuf, M., Porcelli, D., Pröhl, G. \& Twining, J., 2017. The environmental behaviour of polonium, International Atomic Energy Agency. doi: 10.1016/0883-2927(92)90073c.

Carvalho, F.P. 2018. Radionuclide concentration processes in marine organisms: A comprehensive review, Journal of Environmental Radioactivity, 186:124-130. doi: 10.1016/j.jenvrad.2017. 11.002.

Eckerman, K., Harrison, J., Menzel, H.G. \& Clement, C.H., 2013. ICRP publication 119: Compendium of dose coefficients based on ICRP publication 60, Annals of the ICRP, 42(4):1-130. doi: 10.1016/j.icrp.2013.05.003.

Guy, S., Gaw, S., Pearson, A.J., Golovko, O. \& Lechermann, M. 2020. Spatial variability in Polonium-210 and Lead-210 activity concentration in New Zealand shellfish and dose assessment. Journal of Environmental Radioactivity. 211:p.106043. doi: 10.1016/j.jenvrad.2019.106043.
IAEA. 2017. Guidelines for the Sampling, Preparation and Radio-Analysis of Marine Matrices. doi: 10.1177/0964663912467814.

Khan, M.F. \& Wesley, S.G. 2016. Baseline concentration of Polonium-210 (210Po) in tuna fish, Marine Pollution Bulletin, 107(1): 379382. doi: 10.1016/j.marpolbul.2016.03.056.

Khan, M.F., Wesley, S.G. \& Rajan, M.P., 2014. Polonium-210 in marine mussels (bivalve molluscs ) inhabiting the southern coast of India, Journal of Environmental Radioactivity. 138:410-416. doi: 10.1016/j.jenvrad.2014. 06.023.

Kim, S.H., Hong, G.H., Lee, H.M. \& Cho, B.E. 2017. 210Po in the marine biota of Korean coastal waters and the effective dose from seafood consumption, Journal of Environmental Radioactivity, 174:30-37. doi: 10.1016/j.jenvrad.2016.11.001.

Kristan, U., Planinšek, P., Benedik, L., Falnoga, I. \& Stibilj, V., 2015. Polonium-210 and selenium in tissues and tissue extracts of the mussel Mytilus galloprovincialis (Gulf of Trieste), Chemosphere, 119:231-241. doi: 10.1016/j.chemosphere.2014.05.017.

Lasabuda, R. 2013. Pembangunan Wilayah Pesisir Dan Lautan Dalam Perspektif Negara Kepulauan Republik Indonesia, Jurnal IImiah Platax, 1:92-101.

Makmur, M., Prihatiningsih, W.R. \& Yahya, M.N., 2020. Baseline concentration of Polonium210 (210Po) in several biota from Jakarta Bay, IOP Conference Series: Earth and Environmental Science, 429(1):p012061 doi: 10.1088/1755-1315/429/1/012061.

Meli, M.A., Desideri, D., Roselli, C. \& Feduzi, L., 2014. Assessment of 210Po in Italian diet. Food chemistry, 155:87-90. doi: 10.1016/j. foodchem.2014.01.049.

Munawwarah, A., Sufi, I. \& Noviyanti, A. 2016. Identifikasi Jenis-jenis Ikan yang Terdapat di Tempat Pelelangan Ikan (TPI) di Gampong Lampulo Kecamatan Kuta Alam Banda Aceh, Serambi Saintia : Jurnal Sains dan Aplikasi, 4(1):44-50.

Nathwani, A.C., Down, J.F., Goldstone, J., Yassin, J., Dargan, P.I., Virchis, A., Gent, N., Lloyd, D. \& Harrison, J.D. 2016. Polonium210 poisoning: a first-hand account, The Lancet, 388(10049):1075-1080. doi: 10.10 16/S0140-6736(16)00144-6.

Nelson, A.W., Eitrheim, E.S., Knight, A.W., May, D., Wichman, M.D., Forbes, T.Z. \& Schultz, M.K., 2017. Polonium-210 accumulates in 
a lake receiving coal mine dischargesanthropogenic or natural?, Journal of Environmental Radioactivity. 167:211-221. doi: 10.1016/j.jenvrad.2016.10.023.

Pearson, A.J., Gaw, S., Hermanspahn, N. and Glover, C.N., 2016. Activity concentrations of 137Caesium and 210Polonium in seafood from fishing regions of New Zealand and the dose assessment for seafood consumers, Journal of Environmental Radioactivity. 151:542-550. doi: 10.1016/j.jenvrad.2015.07.026.

Poerwadi, B.S. 2017. Pokok-Pokok Kebijakan Kementerian Kelautan dan Perikanan tentang Pemberdayaan dan Potensi Ruang Laut dan Pulau-pulau terluar, Humas KKP. Available at: kkp.go.id / ancomponent , media s djprl , HUMAS.

Rani, L.M., Jeevanram, R.K., Kannan, B.V. \& Govindaraju, 2014. Estimation of Polonium-210 activity in marine and terrestrial samples and computation of ingestion dose to the public in and around Kanyakumari coast, India, Journal of Radiation Research and Applied Sciences. 7(2):207-213. doi: 10.1016/j.jrras.2014.02. 006.

Ram, R., Vaughan, J., Ełschmann, B. \& Brugger, J. 2019. The aqueous chemistry of polonium (Po) in environmental and anthropogenic processes, Journal of Hazardous Materials. 380:p120725. doi: 10.1016/j.jhazmat.2019.06.002.

Rizwan, Purnawan, S., \& Miswar, E. 2010. Study of oceanography and fisheries in Pulo Aceh Waters, Jurnal Natural, 10(2):35-42.

Skwarzec, B. \& Fabisiak, J. 2007. Bioaccumulation of polonium 210Po in marine birds, Journal of Environmental Radioactivity, 93(2):119-126. doi: 10.1016/ j.jenvrad.2006.12.005.

Sorenson, L., Santini, F., Carnevale, G. and Alfaro, M.E., 2013. A multi-locus timetree of surgeonfishes (Acanthuridae, Percomorpha), with revised family taxonomy, Molecular Phylogenetics and Evolution. 68(1):150160. doi: 10.1016/j.ym pev.2013.03.014.

Streelman, J.T., Alfaro, M., Westneat, M.W., Bellwood, D.R. \& Karl, S.A 2002. Evolutionary history of the parrotfishes: Biogeography, ecomorphology, and comparative diversity, Evolution, 56(5): 961-971. doi: $10.1111 / \mathrm{j} .0014-3820.2002 . t b 0$ 1408.x.

UNSCEAR. 2000. Sources and Effects of lonizing Radiation, United Nations Scientific Committee on the Effects of Atomatic Radiation. United Nations, New York. 